\title{
Mutations of Turkish Nationalism: From Neo-Nationalism to the Ergenekon Affair
}

\author{
Ioannis N. Grigoriadis and Irmak Özer
}

Dr. Grigoriadis is assistant professor at the Department of Political Science, Bilkent University, in Ankara, and Ms. Özer is a graduate of the Faculty of Arts and Sciences, Sabancı University, in Istanbul.

W hen Turkey was trying to recover from the 2001 financial crisis and reform efforts by the European Union (EU) were gaining momentum, the secretary general of the powerful National Security Council (Milli Güvenlik Kurulu, MGK), General Tuncer Kılınç, claimed during a conference at the Istanbul Military Academies Directorate on March 7, 2002, that he opposed Turkey's membership in the EU, adding:

\section{Turkey absolutely needs to seek new alliances. In my opinion, the best direction would be to seek an alliance with the Russian Federation, which would include Iran, without ignor- ing the United States - if possible. Turkey has not received any help from the European Union. The European Union has negative approaches to the problems that concern Turkey. ${ }^{1}$}

This statement caused shock; the army was thought to support, if not Turkey's democratic consolidation, at least its Western orientation. Some years later, the unraveling of the Ergenekon affair showed that Kılınç was not a "black swan." As (C) 2010, The Authors
EU-Turkey relations improved in the early 2000 s, a new thread of Turkish nationalism emerged, a paradoxical mix of Kemalism and anti-Westernism that found support in military ranks, posed additional obstacles to Turkey's reform process and threatened its democratic regime per se.

Such opinions came as a surprise to many. At a moment when the Western and democratic credentials of Turkish political Islam were questioned by the Kemalist media, the army was seen as an anchor of the country's Western orientation. And then, one of the country's most senior military officers appeared to prefer Turkey's alliance with Russia, the archenemy of the Ottoman Empire, or - even more bizarrely - with the Islamic Republic of Iran. In fact, Kilınç was not alone in his aberration from the Western vision of Kemalist orthodoxy. When the process of Turkey's European integration made clear that its full membership in the European Union would require the end of the military's tutelage over Turkish politics and society, some officers opted for the preservation of their institutional prerogatives. Advancing an anti-Western, isolationist agenda would secure the survival of the Kemalist status quo 
Middle East Policy, Vol. XVII, No. 4, Winter 2010

and also bring Turkey closer to states that are strong but not famous for their democratic credentials, such as Russia and Iran. What came to be known as Turkey's neonationalism, or ulusalcılık as it is referred to in Turky, combines the anti-democratic elements of the Kemalist bureaucracy with the anti-Western attitudes of traditional political Islam, the far right and the far left. This synthesis, which Kılınç personified, has been a pervasive feature of Turkey's disparate anti-EU alliance. Its traces can be found in the Ergenekon affair, which is explored below.

\section{THE ARGUMENT}

Nationalism is one of the most enduring themes of Turkish politics, but it is by no means static. This study aims to explore one of its most salient recent mutations, neo-nationalism. It will explore its historical roots and relations with traditional currents of Turkish nationalism, as well as its domestic and foreign-policy implications. The Ergenekon affair is examined as a case demonstrating the strength of the neo-nationalist movement as well as the threat that it could pose for Turkish democracy. This study argues that ulusalc1lik is distinct from traditional versions of nationalism, as it simultaneously claims loyalty to Kemalist orthodoxy and opposes Turkey's Westernization. As strict ideological divisions that caused serious clashes during the 1970s dissipated in the aftermath of the Cold War, it became possible for leftist and rightist forces to collaborate to avert what they see as the biggest threat, Turkey's European integration. It also comprises an interesting example of how "uncivil society,"2 which opposes globalization, often benefits from it and adjusts its message and operating methods to new social and economic circumstances.
This study focuses on the controversial Ergenekon affair because it highlights the relevance of ulusalc1lik to Turkish politics. Ulusalc1lik feeds on the chronic trust deficit that has characterized Turkey's relations with its neighbors but has now come to shape relations between Turkey's religious conservative and secularist classes. The Ergenekon affair indicates the threat that an unprecedented alliance of disparate elite and underdog social elements could pose to the prospect of Turkey's democratic consolidation and European integration. It also documents an emerging fragmentation within the ranks of the Turkish military and judiciary regarding the continuation of the tutelary role of the Turkish bureaucracy.

\section{HISTORICAL ROOTS \\ The Left}

Thanks to the relatively liberal political framework set by the 1961 constitution, a vibrant ideological openness characterized Turkey in the 1960s and 1970s. The Yön (Direction) Movement was one of the leftist groups founded in the 1960s under the leadership of Doğan Avcioğlu and Mümtaz Soysal. Yön had a close relationship with the bureaucracy, as well as the Republican People's Party (Cumhuriyet Halk Partisi, CHP). It can be defined as a leftist-nationalist movement that defended Turkish exceptionalism, anti-imperialism — a.k.a. Westernism — and Jacobinism. ${ }^{3}$

Another major leftist trend was the National Democratic Revolution movement (Milli Demokratik Devrim, MDD), which emerged from the ranks of the Labor Party (İsçi Partisi, İP). The end of the Cold War brought radical change to MDD as well as to Yön. Nationalism came to stand for socialist ideals and provide a raison d'être for the continuation of these movements. While still embracing socialism, the leading 
magazine of the MDD movement, Aydınlık, gradually adopted a nationalist, anti-imperialist, national-unionist, anti-Kurdish, antiIslamic rhetoric and claimed to represent Kemalist orthodoxy in the arena of civilian politics. ${ }^{4}$ Anti-imperialism became the bridge that linked leftism and nationalism. Although this transformation was gradually alienating them from their European counterparts, it facilitated their reconciliation on a common anti-Western, nationalist agenda embroidered with fragments of their old leftist ideology. By the end of the 1990s, they formed a political agenda that vehemently opposed those whom they called enemies within (iç düşman), collaborators with the Western imperialist plans for Turkey. The latter included the liberals and, most important, the Justice and Development Party (Adalet ve Kalkinma Partisi, AKP), founded in 2001 on Islamist political roots that did not prevent it from launching a radical EU reform program when it came to power in November 2002.

\section{The Right}

Throughout the 1960s, rightist intellectuals tried to make a strong argument to counterbalance the dominant leftist discourse. In 1970, the "IntellectualsHearth" (Aydinlar Ocăgl) was formed to defend the "national culture" against leftist ideas. Its ideology was crystallized under the leadership of Ibrahim Kafesoğlu, who conceptualized the core of the "TurkishIslamic Synthesis" (Türk-İslam Sentezi), ${ }^{5}$ aimed at reconciling Turkishness with Islam by claiming that the Turks converted to Islam voluntarily and revived and spread the religion in Ottoman times. ${ }^{6}$ At the international level, the Turkish-Islamic Synthesis underlined Turkey's soft power through its emphasis on Ottoman history and its rich Islamic culture. ${ }^{7}$ On the other hand, it caused a rift in domestic politics by confronting the anti-Islamic legacy of the Atatürk reforms.

By the mid-1970s, the impact of these ideas was felt in state policies. Aydınlar Ocağ did not identify with one political party. While its nationalism and Islamic arguments appealed to parties such as the Nationalist Action Party (Milliyetçi Hareket Partisi, MHP), its base was impatient with its elitist and statist positions. The 1980 coup d'état became a windfall opportunity for Aydınlar Ocağ $1 .{ }^{8}$ Its ideas gained an unexpected prevalence and legitimacy when the military regime of General Kenan Evren ${ }^{9}$ adopted the Turkish-Islamic Synthesis as its official ideology. ${ }^{10}$ The group blossomed with the rise to power of Turgut Özal, said to be one of the prominent members of the group. During his tenure as prime minister, many other members were appointed to high positions in the state bureaucracies and universities. ${ }^{11}$ Leftist groups viewed these developments as a direct threat to the secular nature of the state.

In due course, following the departure of Evren, the military also grew increasingly concerned about the rising role of Islam in state and society. Yet the pace of transformation soon surpassed Aydınlar Ocağı. Özal and his Motherland Party (Anavatan Partisi, ANAP) were moving towards a more pragmatic approach with the changing world order after the Cold War. The strict conservative principles of Aydinlar Ocağ $\breve{1}_{1}$ no longer resonated with the public. Although its political significance waned, its legacy can still be traced in several anti-EU arguments. During the 1970s and 1980 s, it popularized ideas that are common today among Turkish nationalists, such as the conventional wisdom that the West plans to destabilize Turkey by rekindling the Kurdish and Armenian issues. ${ }^{12}$ 
Middle East Policy, Vol. XVII, No. 4, Winter 2010

\section{The Red Apple Coalition}

The leftist and rightist groups examined above were at opposing ends of the ideological spectrum. Under the polarized conditions of the 1960s and especially the 1970s, ideological opposition took extremely violent forms. This could not conceal the fact that these groups often shared common ideas. Both ends championed elitism and a tutelary role for the army in politics and society. In addition, neither supported liberalism; they believed in the absolute priorities of the state over individual interests. Last but not least, they shared anti-imperialism as a guiding principle of their worldview; both believed that Turkey is surrounded by imperialist enemies trying to break it apart.

The end of the Cold War erased the basis of discord between the leftist and rightist groups. The establishment of a communist regime was no longer a hope or a threat. Each group had to reshape its ideology in accordance with the new political and social conditions. Opposition to globalization and the American "new world order" became the key rallying point for their frustrated young supporters, as can be seen in the various ulusalc1 publications such as Cumhuriyet, Aydınlık and Yeni Çăg. This meshed well with their entrenched opposition to imperialism. The emergence of a de facto common agenda allowed for a gradual rapprochement between the one-time ideological rivals and indicated prospects for cooperation. In the words of a rightist professor, Burhan Baloğlu,

....something called globalization has emerged. One of its outcomes is the rise of ethno-nationalism both in the world and in Turkey. These kinds of ethno-nationalism directly aim at Turkey. The West is trying to break the country apart with the excuse of globalization. In an environment like this, leftists reconciled with the panTurkists (Türkçü). ${ }^{13}$

Yön and Aydınlar Ocağg 14 developed a common vocabulary for virtually all key political issues: the Kurdish question, the Cyprus problem, the role of Islam in politics and society, Turkey's EU integration aspirations, and relations with the United States. They saw in any reform attempt a Western plot to destroy Turkey. Their aim was to make Turkey powerful while fully independent from the West. The mainstream ideology that the new leftists adopted was a reinvented version of antiimperialist and anti-Western Kemalism, whose aim was to save the country from its imperialist enemies. ${ }^{15}$ As a result, the distinction between leftist and rightist nationalism has lost a large part of its significance. ${ }^{16}$ The old, violent ideological clashes over communism and Islamism have given way to minor disagreements over the roles of religion and Kemalism in the state.

U.S. policy towards the Middle East under George W. Bush, the invasion and occupation of Iraq, the implications for Turkey's Kurdish question, the increasing problems in EU-Turkey accession negotiations, and the Cyprus question have all facilitated a rise in nationalist sentiment since 2005. Books like Those Crazy Turks (Şu Çılgın Türkler) and Metal Storm (Metal Firtına) and movies like The Valley of the Wolves - Iraq (Kurtlar Vadisi - Irak) have enjoyed unprecedented commercial success ${ }^{17}$ and comprise prime examples of a popular culture that is aggrandizing the new nationalism and mobilizing the Turkish public around a "pax Turca. "18 In addition, the symbols of nationalism have become tools of popular culture and are further awakening popular support. ${ }^{19}$ 
It is the new Turkish nationalism, amalgamated from left and right elements since the end of the $1990 \mathrm{~s},{ }^{20}$ that is called ulusalc1lik. According to Ferhat Kentel, it is "another sub-category of nationalism, but its starting point is more recent, and it refers to a social-engineering version of Turkish modernization, where urban lifestyle is turned into a community." ${ }^{21}$ According to the former general secretary of the Turkish Communist Party (Türkiye Komünist Partisi, TKP), Nabi Yağc1, when the revolutionary period of the 1920 s came to an end, Kemalism started to function as a status-quo force. While the ideology claimed to be the protector of previous revolutions, it actually did not promote the earlier reforms; it blocked any change that threatened the statist understanding. In his view, Kemalism lost its leftist essence by forgoing change, continually claiming that "the regime" was in danger and had to be protected from its own people. ${ }^{22}$

Ulusalcı figureheads such as Burhan Baloğlu and Kemal Çapraz claim that Kemalist principles were weakened during the Cold War. ${ }^{23}$ The imperialist West took the opportunity to rekindle a fratricidal left-right dispute that dissipated the energies of Turkey's youth. Following the Cold War, young people could focus on the realization of a "free, independent Turkey." The ulusalcis gathered under the Kizll Elma (Red Apple) Coalition to revive the Kuva-i Milliye ${ }^{24}$ soul and counterbalance the imperialist powers. ${ }^{25}$ As journalist Murat Yetkin explains,

\footnotetext{
"Klzll Elma is a product of Turkish mythology, like Ergenekon. It represents a Pan-Turkist ideal. The perception was the gathering of leftist nationalists due to the 'red' term in it, with the Turkist nationalists, for the love of the nation." ${ }^{26}$
}

Thereby, K1z1l Elma has enjoyed a diverse membership, from rightist authors to military officers to far-left intellectuals. From its ranks, several key figures involved in the Ergenekon affair have emerged.

Ulusalc1lik strikes with anti-Western rhetoric, despite its claim to Kemalist orthodoxy. ${ }^{27}$ There is constant fear of the fragmentation of the country and mistrust of Western states, international organizations and Turkey's neighbors. Ulusalc1 publications are replete with conspiracy theories, which usually oscillate around the "Sèvres Syndrome." 28 All the great powers are accused of planning Turkey's partition through the use of both internal and external enemies. The European Union is considered a key actor in Turkey's disintegration through its promotion of a resolution of the Cyprus issue, as well as rights for Kurds, Alevis and other minorities. The United States is conceived as evil, due to its military and political involvement in the Middle East. Ulusalcis oppose any cooperation between Turkish armed forces and the United States. They support isolationism and the development of special links with countries like Iran, Russia and China, while objecting to any change in official foreign-policy positions. They object to concessions, negotiation and mediation in any of Turkey's international disputes. They deeply resent the AKP government, which is perceived to be pro-EU, to have close relations with the United States and to be looking for compromise solutions to foreign-policy problems. ${ }^{29}$ Ulusalc1 associations $^{30}$ accused anyone who would take a liberal step in foreign policy as a traitor selling out the country and its ideals. Ulusalcis argue that Turkey is better off alone; any kind of alliance with the West undermines its power and even stability. 
The rise of ulusalcilik was facilitated by developments within the Turkish left. Until the 1980s, the main ideological debate on the left was about selecting the true path towards communism. Following the end of the Cold War, disoriented leftists sought a new direction by embracing antiimperialism. Maintaining their belief in the key political role of social movements, they argued that these movements would be able to oppose capitalism and globalization. By substituting anti-imperialism for communism, they soon entered the realm of nationalism. The same people who were defending the universal values of communism were now explaining their ideology in a national-security framework. Support for universalistic ideas receded in favor of nationalism. Leftists were defending "the brotherhood of the people" (halklartn kardeşliği) until the 1980s, but their rhetoric in the 1990s turned nationalist, anti-minority and xenophobic. Last but not least, relations between the leftists and the military have changed. Although the left never denied the importance of the army, the army's relations with the leftists had been rather unfriendly until the 1990s. The military had considered communism one of the gravest threats against the republic. ${ }^{31}$ However, the shift towards securitization has drawn many old leftists to the same side as the army.

\section{THE MAP OF NATIONALISM Ulusalcı Associations}

The seeds of ulusalc1lik emerged among elite city dwellers and media during the 1990s. The new trend was defined as a "mutation of Kemalist nationalism in the era of globalization." 32 According to the journalist Ertuğrul Özkök, ulusalcıs were "Western-looking youngsters from the metropolises that will make Turkey one of the
Western countries." ${ }^{33}$ In the early 2000 s, the propagation of these ideas was facilitated by the rise of "pop-nationalism." Victories of national athletes and artists often gave nationalist expression an entertaining, carnival-like spirit. ${ }^{34}$ The instrumentalization of this spirit peaked in 2007 during the "Republic demonstrations" (Cumhuriyet Mitingleri), a series of anti-government events organized in Istanbul, Ankara, Izmir and other big cities to oppose the election of an AKP candidate to the presidency of the Republic of Turkey.

Being prime examples of "uncivil society," ulusalc1 associations were keen on using the new technologies, opportunities and methods provided by globalization to disseminate their political message. ${ }^{35}$ The National Force Association (Kuva-i Milliye Derneği), the Great Union of Jurists (Büyük Hukukçular Birliği) and the Association of Ataturkist Thought (Atatürkçü Düşünce Derneği) are some of the associations that spearheaded the ulusalc1 movement. Several of them were headed by retired officers. These associations have also had close links to parties like the İP and formerly leftist media, such as the daily Cumhuriyet and the magazine Aydınlık. The movement garnered strong support from the journalist Tuncay Özkan, who turned his TV channel, Kanal Türk, into an unofficial organ of the ulusalc1 movement and also founded the "How many people are we" movement (Biz Kaç Kişiyiz Hareketi). Ulusalc1 mobilization also used the internet extensively. New ulusalc1 websites and forums appeared regularly and became popular among Turkish youth. ${ }^{36}$

Benefiting from the rising polarization of Turkish society, ulusalc1 associations were able to appeal to a large part of Turkey's secularist middle class. The rallies were supposed to be a reaction against the 
AKP for the perceived threat that the election of an AKP candidate to the presidency would pose to the republic. They turned, however, into a vehicle for ulusalc1 personalities. The crushing victory of the AKP in the July 2007 parliamentary elections was the first blow against the ulusalc1 movement. It showed that, despite the large demonstrations, the movement represented only a small minority of the Turkish people. A second, heavier blow was dealt with the uncovering of the Ergenekon affair.

\section{Nationalist Associations}

Nationalist associations such as the Hearths of Idealism (Ülkü Ocakları) have long been a fixture of politics in Turkey. Ülkü Ocakları has always been the focal point of the MHP's young militant base, where the ideological identity of the community is determined. The associations have been more radical than the MHP proper in terms of ideological lines and political activities. ${ }^{37}$ Nationalist associations were always suspected of involvement in criminal activities; their aggressiveness and strong tendency towards physical violence were often a source of embarrassment for the MHP, which tried to veil and contain them. ${ }^{38}$

In the $1990 \mathrm{~s}$, these associations faced the challenge of pop-nationalism, espoused by young, mainly uneducated, sympathizers. Pop-nationalism was a "risk-free, loose relationship between the oblivious sympathizers and the nationalist community"; pop-nationalists participated in demonstrations in places like bars, football grounds and nightclubs using nationalist slogans as a form of entertainment without actually taking sides or even understanding the ideology. ${ }^{39}$ On the other hand, the traditional leaders thought they should not altogether reject these potential followers, despite the fact that the pop-nationalists lacked cohesion and homogeneity, were not able to fully adopt "national and moral values," were insensitive towards Islam, and evinced an ideological-moral gap.

These worries reflected nationalist discomfort towards fast-spreading modernization and globalization. ${ }^{40}$ These pop-nationalists, unlike the older generation, did not attend the Ülkü Ocaklar1. Furthermore, they were using MHP symbols, although they were not affiliated with the party or the "elders" of the associations. Despite these concerns, nationalist associations loosened their rules and engaged their new clientele using their symbols or slogans in the protests, football matches and so forth. The movement was popular both in the slums and among the middle- and upper-class city dwellers. This had no precedent in the history of Turkish nationalism, in which its elite and underdog factions were normally separated. ${ }^{41}$

All in all, nationalist associations have maintained their key features while, since the 1990s, addressing a wider and more diverse clientele. They are still greatly attached to values such as the Turkish-Islamic synthesis, pan-Turkism and an alleged Turkish folkloric heritage (such as Dokuz Işı $\downarrow$, Ergenekon and Kızıl Elma). Nevertheless, they have been able to appear less strict and more flexible, allowing them to reach a wider audience. This outreach apparently has had major political consequences. Under the extraordinary political circumstances of the early 2000 s, segments of nationalist associations cooperated with ulusalcis in what may be the greatest conspiracy against Turkey's democratic regime since 1980: the Ergenekon affair.

\section{The Ergenekon Affair}

On June 12, 2007, 27 hand grenades were found in the flat of retired officer Oktay Y1ldırım in Ümraniye, Istanbul. 
Middle East Policy, Vol. XVII, No. 4, Winter 2010

Evidence uncovered by police provided the key to uncovering the Ergenekon organization, a fruit of the cooperation between the Turkish "deep state" (derin devlet) and far-right extremists. Named after the mythical location of the birth of the Turkish nation, Ergenekon has a membership base consisting of followers of both nationalist and ulusalc1 groups: retired military and police officers, intellectuals and lawyers, as well as rogue elements. Although a direct relationship between the Ergenekon organization and the ulusalc1 movement cannot be substantiated, Ergenekon is a product of the ideological fermentation in which ulusalc1 associations have played a catalytic role. The list of Ergenekon defendants ranged across the Turkish political spectrum from left to right. In addition, the very same rallying points - anti-imperialism, fear of globalization, fear of disintegration and mistrust of the AKP - that brought together the Red Apple Coalition appear to have constituted the reasons for the establishment of the Ergenekon group.

Ergenekon's roots can be traced to the parastatal organizations founded with U.S. support in Southern European countries $^{42}$ in the aftermath of World War II to avert the real or perceived threat of a communist takeover. Yet, while in Greece or Italy these organizations were eventually neutralized by the late 1970 s, they remained largely intact in Turkey and were even revitalized by the 1980 coup. According to the indictment, the Ergenekon group was determined to derail what they saw as Turkey's course towards partition, namely democratization. They developed links to organized crime with the aim of orchestrating the assassination of prominent liberal intellectuals and minority leaders: Orhan Pamuk, Turkey's first and only Nobel Prize winner; Kurdish political leaders such as Ahmet Türk, Leyla Zana, Sebahat Tuncel and Osman Baydemir; as well as Fehmi Koru, columnist for the liberal Islamist daily Yeni Şafak. Through these acts, they planned to provoke one more military coup in 2009, bringing Turkey's democratization process and EU accession negotiations to a precipitous end.

Ergenekon suffered a first heavy blow on January 23, 2008, when 33 people were arrested, including Veli Küçük, a retired army general; Fikret Karadağ, a retired army colonel; Sami Hoştan, a key figure in the Susurluk affair, a car accident in 1996 that shocked Turkey by revealing the links between the deep state and organized crime; Güler Kömürcü, a columnist of the daily Akşam; and Kemal Kerinçsiz, ${ }^{43}$ a lawyer who repeatedly attracted publicity through his lawsuits against Ecumenical Patriarch Bartholomew and Orhan Pamuk, as well as the organization of an academic conference on the Armenian question in 2005.

Küçük, seen as the most prominent of all the detainees, was thought to be the founder of JITEM (Jandarma İstihbarat ve Terörle Mücadele), a clandestine organization of the Turkish Gendarmerie and an indispensable component of the deep state. JITEM had the alleged mission to instigate terrorist attacks that would then be attributed to other groups, Islamist or nationalist. He was suspected of involvement in the assassination of a senior judge on Turkey's Supreme Administrative Court in May 2006, a bomb attack against the Istanbul premises of the secularist daily Cumhuriyet in the same month, and even the assassination of the Armenian journalist Hrant Dink in January 2007. Evidence found during the police operation only reinforced these suspicions. 
As the Ergenekon affair was unfolding, many commentators made a careful distinction between what they called the "small" and the "big" Ergenekon. The "small" Ergenekon referred to the group of officers, lawyers, journalists and others arrested in the police operations of January 2008. Most of these detainees belonged to the fringe of Turkish society and traditional nationalist groups and had limited social status and appeal. The "big" Ergenekon referred to a group of generals, leading journalists and academics who belonged to ulusalc1 circles and were suspected to be the masterminds behind the Ergenekon group. Most columnists doubted that the investigation would dare to touch them. The arrests on March 23, 2008, of İlhan Selçuk, chief columnist of the daily Cumhuriyet; Doğu Perinçek, leader of the Workers' Party (İşçi PartisiİP); and Kemal Alemdaroğlu, former rector of Istanbul University, gave the first hint that the prosecutors would not be willing to spare prominent suspects. ${ }^{44}$ Yet few expected the twist the events took on July 1, 2008, when two retired four-star generals, Şener Eruygur and Hurşit Tolon, were among a group of high-profile suspects detained. ${ }^{45}$ Eruygur was the president of the Ataturkist Thought Association (Atatürkçü Düşünce Derneğ $i$, ADD), an NGO that took a leading role in organizing the massive anti-AKP "Republic demonstrations" in spring 2007, which aimed to avert the appointment of a prominent AKP figure to the presidency of the country.

In a state where the military has been held as untouchable and the perpetrators of military coups have not been held accountable for their deeds, these arrests were indeed a seminal event. In a 2,455-page indictment against 86 persons involved in the Ergenekon affair, charges referred to organizing an armed terror group and orchestrating a coup attempt. However, this document did not include charges against the latest group of defendants, including Eruygur and Tolon. These followed in a separate indictment. The untouchability of the Turkish military was questioned for the first time. Several waves of arrests followed until, on Wednesday, January 7 , 2009, a new series of arrests involved 30 persons, including three retired generals, Erdal Şenel, Kemal Yavuz and Tuncer Kilınç, the general who had made the controversial statement in 2002; a former president of the Higher Education Council (Yüksek Öğretim Kurulu, YÖK), Kemal Gürüz; and nine low- and mid-level activeduty officers.

Reaction to the new judicial actions was varied. ${ }^{46}$ Chief of the General Staff İlker Basbuğ had a six-hour meeting with the commanders of land, air and sea forces. Thereafter, he had unannounced meetings with President Abdullah Gül and Prime Minister Recep Tayyip Erdoğan in an apparent attempt to show the military's serious concern about these developments. ${ }^{47}$ The news had a negative impact on the financial market, which slumped more than 5 percent on that day.

The arrest of the generals brought attention to a news story from the magazine Nokta of March 2007. ${ }^{48}$ Nokta published what it claimed to be excerpts from the diary of retired Admiral Özden Örnek. They included information about two coup plots, Sarıkız and Ayışığ , against the AKP government in 2004 organized by Eruygur, Tolon and other top-ranking officers. Shortly thereafter, Örnek claimed that the documents were forgeries. The police raided the offices of Nokta, and the magazine had to suspend publication. Following the arrest of Eruygur and Tolon, information 
reinforcing the Nokta claims appeared in the media, in addition to information about two additional coup plots, Eldiven and Yakamoz, and a set of covert operations aiming to wreak social havoc, polarize existing divisions in the country and create conditions facilitating a military coup. Both Eruygur and Tolon had acquired leading positions in Turkey's nationalist-secularist civil society in the aftermath of their retirement. Allegations arose that increasing pressure against the AKP government was not only limited to peaceful demonstrations. It may have included the murder of the Catholic priest Andrea Santoro in Trabzon in February 2006, bomb attacks against the offices of Cumhuriyet in May 2006, the attack against Turkey's Supreme Administrative Court (Danıştay) in May 2006 and even the murder of Hrant Dink in January 2007. ${ }^{49}$

No definite judgments can be made about the Ergenekon affair before the court delivers its verdict. Nevertheless, while Ergenekon may shed light on some of the darkest pages of Turkish political history, there have been significant shortcomings related to the legal procedures. Severe violations of the human rights of some defendants were reported..$^{50}$ The treatment of some defendants also became a cause of concern, as in the case of Kuddusi Okkır, who was diagnosed with late-stage cancer while he was in jail and passed away days after his release. The arrest of 83-year-old journalist İlhan Selçuk at 4:30 a.m., ostensibly to prevent him from fleeing - while he was in fact being guarded by the police following numerous death threats by Islamists - was another telling example. ${ }^{51}$ The raid on the house of the 73-year-old and terminally ill Türkan Saylan, founder and president of the Association for the Support of Progressive Life (Çăğdaş Yaşamı
Destekleme Derneği, ÇYDD), ${ }^{52}$ was also perceived as retaliation for ÇYDD activities promoting secular education. ${ }^{53}$ In the view of some analysts, the Ergenekon affair served as a pretext for the AKP to purge its political and ideological opponents and consolidate its hegemony. ${ }^{54}$

On the other hand, the major opposition Republican People's Party (CHP) openly took the side of the defendants. Ever since the outbreak of the Ergenekon affair, CHP members have argued that Ergenekon is an AKP ploy to eliminate its political opponents. The CHP leader Deniz Baykal even came to the point of arguing that, "if the Prime Minister is Ergenekon's prosecutor, Deniz Baykal is its attorney." 55 Following a wave of arrests in January 2009, Baykal repeated in a special news conference,

$$
\begin{aligned}
& \text {... we are looking at a political case } \\
& \text { and not a legal trial. In this case, } \\
& \text { we don't see the application of the } \\
& \text { law but rather a political settling of } \\
& \text { accounts by the use of the law.... } \\
& \text { We have seen this only in periods of } \\
& \text { regime change, similar to the period } \\
& \text { before Khomeini and Hitler.... }
\end{aligned}
$$

Notwithstanding the significant judicial shortcomings in the Ergenekon process, this statement showed that the CHP seemed to line up with the most radical elements in the bureaucracy, leaving its allegiance to the rule of law and democratic principles in question. The new leader of the CHP, Kemal K1lıçdaroğlu, who succeeded Baykal in May 2010 and was expected to reconfigure his party's relations with the state bureaucracy, did not depart from his predecessor's policy on this.

The unraveling of the Ergenekon affair has shown the significance of ulusalc1lik for Turkish politics and is a milestone for 
ulusalc1 associations and nationalist mobilization in Turkey. While not all ulusalc1 associations were involved in Ergenekon, a large number of the Ergenekon defendants were leading figures of the ulusalc1 movement. Opposition to the AKP government and the reforms that are seen as an essential part of Turkey's democratic consolidation and European integration united a disparate group of elite and underdog nationalist and ulusalc1 elements. While ulusalc1 associations gained the support of a considerable part of the secularist middle class through their campaign against the adulteration of Turkish secularism by the AKP, they suffered a blow through the revelations of the Ergenekon affair. Their alleged links with the deep state put their public legitimacy into question.

Moreover, one of the most interesting results of the Ergenekon affair is the revelation of significant divisions within the Turkish military and judiciary. It appears that the former chief of the Turkish General Staff, Hilmi Özkök, has been one of the primary targets of the Ergenekon group. Being perceived as weak or even "crypto-Islamist" because of his unwillingness to undertake initiatives against the AKP government, Özkök represented a Turkish military willing to accept the end of its tutelary role. His meeting with President Abdullah Gül aimed at alleviating social tension and his repeated public support for Turkey's EU integration project have reconfirmed this stance. In addition, his refusal to disprove the existence of the Ergenekon-led coup attempts indicates that the case was not simply an AKP forgery against its political opponents.

The same division runs across the judiciary. On the one hand, Turkey's chief prosecutor, Abdurrahman Yalçınkaya, filed on March 14, 2008, a closure case against the AKP, a party that had won approximately 47 percent of the popular vote less than a year before. ${ }^{57} \mathrm{~A}$ decision by the Constitutional Court on June 5, 2008, annulled a constitutional amendment allowing the use of the headscarf and questioned the very principle of popular sovereignty. ${ }^{58}$ On the other hand, Istanbul prosecutor Zekeriya Öz, who, with his assistants Mehmet Pekgüzel and Nihat Taşkın, has been running the investigation of the Ergenekon affair, has become the protagonist in what might be a turning point in the struggle against the deep state. In both the military and the judiciary, there appeared to be a division regarding the role of the bureaucracy in Turkish politics and society. While some were adamant on maintaining the tutelary role the bureaucracy had secured in the early republican years, others were willing to give it up in the process of Turkey's democratic consolidation and adapt to the norms of a fully democratic state.

\section{CONCLUSION}

Turkish nationalism has undergone significant transformation since the 1980s. The end of the Cold War allowed for rapprochement between leftist and rightist forces, which found a common enemy in globalization and Turkey's European integration. The rise of ulusalc1lik is the most characteristic fruit of this process. With an anti-Western and isolationist agenda, it aimed to represent the grievances of segments of Turkey's society. These for the first time included members of the secular elite and underdog nationalists. A plethora of ulusalc1 associations emerged and aimed to counter Turkey's democratic reform process, while benefiting from the tools and opportunities globalization and modernization secured. Their operation has been a prime example of how "uncivil" 
Middle East Policy, Vol. XVII, No. 4, Winter 2010

society can mobilize against the goal of democratic consolidation. In particular, the Ergenekon affair manifested how both traditional and new nationalists could cooperate with the common aim of derailing Turkey's European integration by toppling its democratic regime. The uncovering of the Ergenekon affair has brought to the fore divisions within Turkish society that underline some of the most serious challenges Turkey has ever faced.

${ }^{1}$ Murat Gürgen, “Orgeneral K1lınç: Avrupa Bize Uymaz,” Radikal, March 8, 2002.

${ }^{2}$ To "uncivil society" belong associations that lack "civility," defined as tolerance to different views, cultures and ideologies.

${ }^{3}$ Suavi Aydın, 'Sosyalizm ve Milliyetçilik: Galiyefizm'den Kemalizm'e, Türkiye'de 'Üçüncü Yol'

Arayışları," in Tanıl Bora and Murat Gültenkingil, eds., Milliyetçilik (İstanbul: İletişim, 2002), p. 465.

${ }^{4}$ Ibid., p. 475.

${ }^{5}$ İbrahim Kafesoğlu, Türk-İslam Sentezi (İstanbul: Aydınlar Ocağı, 1985).

${ }^{6}$ Alper Emin and Özgür Sevgi Göral, "Aydınlar Ocağ1," in Ahmet Çiğdem, ed., Muhafazakârlık (İstanbul: İletişim, 2003), p. 583.

${ }^{7}$ Yüksel Taşkın, "Muhafazakâr Bir Proje Olarak Türk-İslâm Sentezi," in Ahmet Çiğdem, ed., Muhafazakârlık (İstanbul: İletişım, 2003), pp. 398-401.

${ }^{8}$ Emin and Göral, “Aydınlar Ocağ 1 ," pp. 584-87.

${ }^{9}$ This regime came to power in a coup on September 12, 1980.

${ }^{10}$ Emin and Göral, “Aydınlar Ocağı,” p. 583.

${ }^{11}$ Ibid., pp. 584-87.

12 Ibid., pp. 588-89.

13 “'Kızıl Elma' Konuşuyor,” Türk Solu, Aug. 18, 2003.

${ }^{14}$ Aydınlar Ocăgl underwent a radical transformation in the 1980 s, when a large part of its membership left the association.

${ }^{15}$ Emrullah Uslu, "Ulusalc1lik: The Neo-Nationalist Resurgence in Turkey," Turkish Studies, Vol. 9, No. 1, 2008, p. 84.

${ }^{16}$ This distinction maintains its significance regarding the role of religion in politics and society. While the leftists put the protection of the Turkish version of secularism instead of communism and universalism in the forefront of their agenda, the rightists remained more tolerant of public manifestations of religious belief and a stronger role for Islam in politics and society as well as keeping their old political aspirations like the "Turanism" and Turkish-Islamic Synthesis.

${ }^{17}$ Ioannis N. Grigoriadis, "Upsurge amidst Political Uncertainty: Nationalism in Post-2004 Turkey," SWP Research Paper 2006, No. 11, 2006, pp. 13-14.

${ }^{18}$ Lerna K. Yanık, "Valley of the Wolves-Iraq: Anti-Geopolitics Alla Turca," Middle East Journal of Culture and Communication, Vol. 2, No. 1, 2009, p. 163.

${ }^{19}$ Umut Özkırıml1, Milliyetçilik ve Türkiye-AB İlişkileri (İstanbul: TESEV, 2008), p. 52.

${ }^{20}$ For a succinct account of varieties of Turkish nationalism in the 1990s, see Tan1l Bora, "Nationalist Discourses in Turkey," South Atlantic Quarterly, Vol. 102, No. 2/3, 2003.

${ }^{21}$ Emin Aydın, “Are 'Milliyetçilik' and 'Ulusalcılık' the Same as Nationalism?” Sunday's Zaman, July 15, 2007.

${ }^{2}$ Nabi Yağc1, “Ulusalc1lık Tamamen Aldatmaca,” Interview with Neşe Düzel, Radikal, Oct. 24, 2005.

23 “'Kızıl Elma' Konuşuyor," op. cit.

${ }^{24}$ Kuva-i Milliye was a Turkish nationalist resistance group active between 1918 and 1922 .

${ }^{25}$ Timur Soykan, “"Kizil Elma’ Koalisyonu,” Radikal, Aug. 3, 2003.

${ }^{26}$ Murat Yetkin, “Ergenekon mu, Kizıl Elma mı?,” Radikal, July, 27, 2008.

${ }^{27}$ While Kemalism itself has had a troubled relationship with the West, best expressed in the saying 'Batı'ya rağmen batılılaşmak" (Westernization in spite of the West), it never jettisoned its essential pro-Western 
orientation. For more on this, see Ali Kazancigil, "Anti-Emperyalist Bağımsızlık Ideolojisi ve Üçüncü Dünya Uluşçuluğu Olarak Kemalizm,” in Ahmet İnsel, ed., Kemalizm (İstanbul: İletişım, 2001), pp. 235-36.

${ }^{28}$ Dietrich Jung, "The Sèvres Syndrome: Turkish Foreign Policy and Its Historical Legacies," American Diplomacy, Vol. 8, No. 2, 2003.

${ }^{29}$ A prime example is the former president of the unrecognized "Turkish Republic of Northern Cyprus" and diachronic figurehead of Turkish nationalism, Rauf Denktaş.

${ }^{30}$ Such associations have proliferated since Turkey's democratization reform and EU membership perspective gained pace in the early 2000s. See, also, Uslu, "Ulusalc1lik: The Neo-Nationalist Resurgence in Turkey," op. cit., pp. 87-88.

${ }^{31}$ For more information on this, see Yüksel Taşkın, "12 Eylül Atatürkçülüğü Ya Da Bir Kemalist Restorasyon Teşebbüsü Olarak 12 Eylül,”, in Ahmet İnsel, ed., Kemalizm (İstanbul: İletişım, 2001).

${ }^{32}$ Tanıl Bora and Kemal Can, Devlet ve Kuzgun-1990'lardan 2000'lere MHP (İstanbul: İletişim, 2004), p. 250.

${ }^{33}$ Ibid., pp. 249-54.

${ }^{34}$ Ibid., p. 545.

${ }^{35}$ On the concept of "uncivil society," see Petr Kopecký, "Civil Society, Uncivil Society and Contentious Politics in Post-Communist Europe," in Petr Kopecký and Cas Mudde, eds., Uncivil Society? Contentious Politics in Post-Communist Europe (Routledge, 2003).

${ }^{36}$ For some of the most popular neo-nationalist internet sources, see: http://www.kuvayimilliye.net/, http:// www.kemalist-iz.com, http://www.ulusalcephe.net/, http://www.heddam.com/, and http://ww.bizkackisiyiz. com.

${ }^{37}$ Bora and Can, op. cit., p. 279.

${ }^{38}$ Ibid., p. 285.

${ }^{39}$ Ibid., pp. 261, 256.

${ }^{40}$ Ibid., pp. 274-75.

${ }^{41}$ Ibid., pp. 255-62.

${ }^{42}$ Similar organizations were Gladio in Italy and IDEA in Greece.

${ }^{43}$ Istanbul Office, "Ergenekon'un Beş Lideri," Radikal, January 24, 2008.

${ }^{44}$ Istanbul Office, "Ergenekon Bombas1," Radikal, March 22, 2008.

${ }^{45}$ Istanbul Office, "Operasyon Terfi Etti: Orgenekon!," Radikal, July 2, 2008.

${ }^{46}$ Istanbul Office, "Ergenekon'da Büyük Operasyon,” Zaman, January 8, 2009.

${ }^{47}$ Ankara Office, "Başbuğ'dan Ankara'da Sürpriz Trafik," Milliyet, January 8, 2009.

${ }^{48}$ Istanbul Office, "Ergenekon Investigation Ends Coup Diary Mystery," Today's Zaman, March 27, 2008.

${ }^{49}$ Uslu, "Ulusalc1l1k: The Neo-Nationalist Resurgence in Turkey," op. cit., pp. 88-89.

${ }^{50}$ It is an irony though that these complaints look very similar to comments made in reports of the European Union, the very institution the defendants are said to have joined forces against.

${ }^{51}$ Gareth H. Jenkins, Between Fact and Fantasy: Turkey's Ergenekon Investigation (Central Asia-Caucasus Institute \& Silk Road Studies Program-Johns Hopkins University-SAIS, 2009), p. 47.

${ }^{52}$ Emrullah Uslu, "Ergenekon Investigation Extends to Academics and NGOs," Eurasia Daily Monitor, Vol. 6, No. 71, 2009; and Jenkins, Between Fact and Fantasy: Turkey's Ergenekon Investigation, p. 76.

${ }^{53}$ In particular, ÇYDD's successful "Father, Send Me to School" (Baba Beni Okula Gönder) campaign aimed to increase the rate of school attendance among girls in eastern and southeastern Turkey. These activities were often perceived as rivaling those of Islamist civil society organizations in the region.

${ }^{54}$ Jenkins, Between Fact and Fantasy: Turkey's Ergenekon Investigation, pp. 80-82.

${ }^{55}$ Ankara Bürosu, Baykal: Savcı Erdoğan ise Avukat Benim (NTVMSNBC: Istanbul, 2008a), available from http://arsiv.ntvmsnbc.com/news/452165.asp [posted on July 4, 2008].

${ }^{56}$ Ercan Yavuz, "Local Elections to be Held under Shadow of Ergenekon," Today's Zaman, Jan. 9, 2009.

${ }^{57}$ Ankara Bürosu, "Yargıtay Başsavcısı AKP’nin Kapatılmasını Istedi: Yok Artık, Daha Neler," Radikal, March 15, 2008.

${ }^{58}$ Ankara Bürosu, “Anayasa Mahkemesi’nden Tarihi Karar: Türban Iptal,” Hürriyet, June 6, 2008. 